\title{
Evaluation of the Estrogenic Activity of the Wild Pueraria mirifica by Vaginal Cornification Assay
}

\author{
Wichai CHERDSHEWASART'1), Yosaporn KITSAMAI ${ }^{2)}$ and \\ Suchinda MALAIVIJITNOND ${ }^{1,3}$
}

\author{
${ }^{1)}$ Department of Biology, ${ }^{2)}$ Biotechnology Program and ${ }^{3)}$ Primate Research Unit, Faculty of \\ Science, Chulalongkorn University, Bangkok 10330, Thailand
}

\begin{abstract}
The aim of this study was to evaluate the estrogenic activity of tuberous samples of phytoestrogen-rich Pueraria mirifica collected from 25 of 76 provinces in Thailand by vaginal cornification assay. Tuberous powders were prepared and administered to ovariectomized rats for 14 consecutive days at dosages of 10,100 and $1,000 \mathrm{mg} / \mathrm{kg}$ BW respectively, and were compared with a daily treatment with $2 \mathrm{mg} / \mathrm{kg}$ BW $17 \beta$-estradiol $\left(\mathrm{E}_{2}\right)$. Rats treated with $10 \mathrm{mg} / \mathrm{kg}$ BW Pueraria mirifica showed no vaginal cornification. Treatment with $100 \mathrm{mg} / \mathrm{kg}$ BW Pueraria mirifica from 13 out of 25 plant samples resulted in development of vaginal cornification. The cell count percentages of the vaginal smeared cells for the treatment with the 2 plant samples that exhibited the fastest vaginal cornification revealed large variation in their estrogenic activities. Treatment with 1,000 mg/kg BW Pueraria mirifica from all plant samples produced vaginal cornification with the mean value for the period (day) of first appearance of cornified cells being 4.08 days compared to 2 days with $2 \mathrm{mg} / \mathrm{kg}$ $\mathrm{BW} \mathrm{E}_{2}$. The overall appearance period (day) of cornified cells during the treatment and post-treatment period with $1,000 \mathrm{mg} / \mathrm{kg}$ BW per day Pueraria mirifica was shorter than treatment with $2 \mathrm{mg} / \mathrm{kg}$ BW $\mathrm{E}_{2}$. The results demonstrate that the plant population shows differential estrogenic activity as evaluated by vaginal cornification assay.
\end{abstract}

Key words: Estrogenic activity, Phytoestrogen, Pueraria mirifica, Rat, Vaginal cornification

(J. Reprod. Dev. 53: 385-393, 2007)

$\boldsymbol{P}$ ueraria mirifica Airy Shaw et. Suvatabhandu [synonym: Pueraria candollei Wall. Ex Benth. var. mirifica (Airy Shaw and Suvat.) Niyomdham] is known to be rich in phytoestrogens. The plant's tuberous roots contain miroestrol [1-3], deoxymiroestrol [4], and isoflavones [5-10]. The estrogenic activity of miroestrol was first determined in ovariectomized rats. Administration of miroestrol produces a mammogenic effect in rats [11]. Using the vaginal cornification assay, miroestrol was estimated to have 0.25 times the

Accepted for publication: November 28, 2006

Published online: January 17, 2007

Correspondence: W. Cherdshewasart

(e-mail: cwichai@sc.chula.ac.th) estrogenic activity of $17 \beta$-estradiol [12]. Thus, various types of research have been conducted on the estrogenic effects of $P$. mirifica, especially in recent years. Crude $P$. mirifica powder can relief the climacteric symptoms of post-menopausal women [13]. The estrogenic activities of $P$. mirifica powder and extract has been evaluated in various species of experimental animals and found to have no toxicity [14]. P. mirifica has biphasic effects on MCF-7 cell proliferation, both suppression and stimulation [15], and an anti-proliferation effect on HeLa cells (ER $\alpha$-negative human cervical adenocarcinoma cells) [16]. Considering the effects on the reproductive organs and reproductive-related hormones, P. mirifica suppresses luteinizing 
hormone (LH) and follicle stimulating hormone (FSH) in male and female rats [17] and female monkeys [18-20] and reduces the levels of bone resorption hormone parathyroid hormone in aged female monkeys [21]. It also initiated the reversal of sexual skin in aged monkeys [22].

$P$. mirifica is widely distributed in deciduous forests throughout Thailand. The tubers of wild plants have been heavily harvested for commercial purposes recently. This could cause not only extinction of the plants in the natural habitat but also loss of plant-derived products. Cultivation of $P$. mirifica with high phytoestrogen content is urgently needed for the plant products at the industrial scale. Screening for estrogenic activity is thus a first essential step for evaluation of quality of plant tubers collected from different sources. We therefore set up bioassays for estrogen activity by means of vaginal cornification assay using a huge number of $P$. mirifica samples collected from 25 out of 76 provinces in Thailand to find and rank the plants with high estrogenic activity based on plant cultivar and collection site.

\section{Materials and Methods}

\section{Plant materials}

The tuberous roots of wild P. mirifica, Family Leguminosae, were surveyed and collected from 25 out of a total of 76 provinces in 5 regions of Thailand (Table 1). To minimize the seasonal variation in phytoestrogen content of $P$. mirifica [23], the plants were collected only in March and April of 2000 [24]. The plants were identified by Cherdshewasart with reference to the study of Kasemsanta et al. [25] and were compared with voucher specimen for P. mirifica (No. BCU 11045) deposited at the Department of Botany, Faculty of Science, Chulalongkorn University (Bangkok, Thailand). Powders were prepared from the tubers as described previously [15].

\section{Animals}

Adult female Wistar rats were supplied from the National Laboratory Animal Center, Mahidol University (Nakhon Pathom, Thailand). They were housed in stainless steel cages (5 animals/cage) with a standard animal husbandry environment of controlled lighting (lights on 0600-2000 h) and temperature $(25 \pm 1 \mathrm{C})$ at the Primate Research
Unit, Department of Biology, Faculty of Science, Chulalongkorn University (Bangkok, Thailand). Rat chow and tap water were provided ad libitum. The animal experiments conducted in the morning between 0800 and $1000 \mathrm{~h}$. The experiment protocol was approved by the Animal Ethical Committee in accordance with the University guideline for the care and use of laboratory animals.

The rats used were 60 days old and 200-250 $\mathrm{g}$ in weight, and each had at least 3 consecutive estrous cycles (4-5 days) before the start of this study. The 5 rats in each group were ovariectomized under ether anesthesia in the diestrous phase of the $4^{\text {th }}$ estrous cycle. The day of ovariectomy was designated as the $1^{\text {st }}$ day of the study period. The rats were divided into the following 3 groups; $P$. mirifica, negative control, and positive control. The treatment schedule was separated into the following 3 periods: pretreatment for 14 days, treatment for 14 days, and post-treatment for 14 days. In the pretreatment and post-treatment periods, the rats were administered $0.7 \mathrm{ml} / \mathrm{kg}$ distilled water. In the treatment period, the rats of the $P$. mirifica group were fed 10, 100 or $1,000 \mathrm{mg} /$ $\mathrm{kg} \mathrm{BW}$ of $P$. mirifica powder suspend in $0.7 \mathrm{ml} / \mathrm{kg}$ distilled water daily, the rats of the negative control group were fed $0.7 \mathrm{ml} / \mathrm{kg}$ distilled water daily, and the rats of the positive control group were subcutaneously injected with $2 \mathrm{mg} / \mathrm{kg}$ BW of $17 \beta-$ estradiol (Sigma, St. Louis, MO, USA) dissolved in corn oil daily, respectively.

\section{Vaginal cornification assay}

The vaginal epithelium was checked daily between 0800 and $0900 \mathrm{~h}$ with the aid of a small glass rod sterilized with $70 \%$ alcohol solution and soaked in $0.9 \%$ normal saline solution before use. The vaginal cells were smeared onto a slide with a drop of $0.9 \%$ normal saline solution, observed under a light microscope, and identified and then their cell types were recorded. Vaginal cells were categorized into the following 3 types: leukocyte cells (L), nucleated cells (O), and cornified cells (Co). The representative cell-type was determined by selecting the type of cells that comprised the majority of cells. The results of examination of vaginal smear cells from 5 rats in each treatment group were expressed as a mode value (the most frequently occurring cell type in 5 rats). The appearance of cornified cells (or a majority of Cotype cells) was used as an indicator of estrogenic 
activity. Thus, 25 cultivars of $P$. mirifica were ranked according to their estrogenic activity. The criteria for ranking were as follows: 1) earlier stimulation of Co-type cell appearance (or the first day of cornified cell appearance) after $100 \mathrm{mg} / \mathrm{kg}$ BW of $P$. mirifica was judged as the higher estrogenic activity, and 2) if the first day of cornified cell appearance was the same between two (or more) cultivars of $P$. mirifica after judgement with the first criterion, earlier stimulation of Co-type cell appearance after 1,000 $\mathrm{mg} / \mathrm{kg}$ BW of $P$. mirifica was used for subsequent judgement for the next step. Since no cornified cell occurred after treatment with $10 \mathrm{mg} / \mathrm{kg}$ BW of $P$. mirifica in all 25 cultivars, the results for this dose were not taken into consideration.

Additionally, the percentage of cornified cells was randomly calculated for the negative control (distilled water) group, positive (17 $\beta$-estradiol) control group, and the two cultivars of $P$. mirifica in the treatment groups (cultivars Kanchanaburi and Mae Hong Son) that showed the highest estrogenic activity. In brief, after evaluation of vaginal smears the 3 types of vaginal cells were counted randomly for total of 100 cells and the percentage of cornified cells were then calculated [26].

\section{Statistical analysis}

The results are expressed as means \pm SEM. The differences in estrogenic activity between the regions of $P$. mirifica collection were analyzed by one-way analysis of variance. Significant differences were then confirmed using the least significant difference (LSD) test. The significance level was set at $\mathrm{P}<0.05$. SPSS version-10 was used for statistical analysis.

\section{Results}

\section{Estrogenic activity of 25 cultivars of $P$. mirifica}

All the rats had only L-type cells throughout the pretreatment period after ovariectomy. Administration of distilled water (negative control group) did not influence on the vaginal epithelium, and only L-type cells were found. In contrast, subcutaneous injection of $2 \mathrm{mg} / \mathrm{kg}$ BW of $17 \beta$ estradiol induced cornification of the vaginal epithelium as early as the second day of treatment, and Co-type cells were retain until the $7^{\text {th }}$ day of the post-treatment period (Fig. 1). The occurrence of vaginal cornification in rats after $P$. mirifica treatment depended on the dose and cultivar. A higher dose of $P$. mirifica produced an earlier response and slower recovery of vaginal cornification. Treatment with $10 \mathrm{mg} / \mathrm{kg}$ BW of $P$. mirifica collected from 25 provinces produced no estrogenic response for any of the samples and no Co-type cells were observed. Treatment with 100 $\mathrm{mg} / \mathrm{kg}$ BW of $P$. mirifica only induced vaginal cornification for 13 out of 25 cultivars. The appearance of cornified cells varied between the $4^{\text {th }}$ and $7^{\text {th }}$ day of the treatment period (Fig. 1). Rats treated with $100 \mathrm{mg} / \mathrm{kg}$ BW of $P$. mirifica collected from the Kanchanaburi and Mae Hong Son had the earliest vaginal cornification responses which occur at the same day (the $4^{\text {th }}$ day). Treatment of 1,000 $\mathrm{mg} / \mathrm{kg}$ BW of $P$. mirifica resulted in development of cornified cells in all rats but with differing first day of appearance, from day $2-8^{\text {th }}$ (Fig. 1). Combining the results of the 100 and $1,000 \mathrm{mg} / \mathrm{kg} \mathrm{BW} P$. mirifica treatments, it was found that the first day of cornified cell appearance after $P$. mirifica treatment was related to the last day of its appearance (Fig. 2; $\left.\mathrm{r}^{2}=0.5446, \mathrm{P}<0.01\right)$. That is, $P$. mirifica with the highest estrogenic activity also exhibited the longest duration of action.

\section{Estrogenic activity of $P$. mirifica based on region}

Based on the first day of Co-type cell appearance after $P$. mirifica treatment at a dose of $100 \mathrm{mg} / \mathrm{kg}$ BW and then at a dose of 1,000 $\mathrm{mg} / \mathrm{kg}$ BW, $P$. mirifica was ranked into 12 levels, arbitrarily designated using numbers between 12 (the highest estrogenic activity) and 1 (the lowest estrogenic activity) (Figs. 1 and 3). The Kanchanaburi cultivar had the highest estrogenic activity, and the Uttraradith and Petchaburi cultivars had the lowest activity. Excluding the East and South regions, from which only one cultivar was collected each, comparison of the estrogenic activity of $P$. mirifica by region showed that the Central-West region had the highest estrogenic activity, but this result was not statistically significant difference $(\mathrm{P}=0.18$ and 0.17 , comparing between Central-West vs. North and Northeast, respectively, Table 1 and Fig. 3).

\section{Estrogenic activity of $P$. mirifica based on the percentage of cornified cells}

Judgement of estrogenic activity based on only the first day of Co-type cell appearance could be problematic if two (or more) cultivars have the 

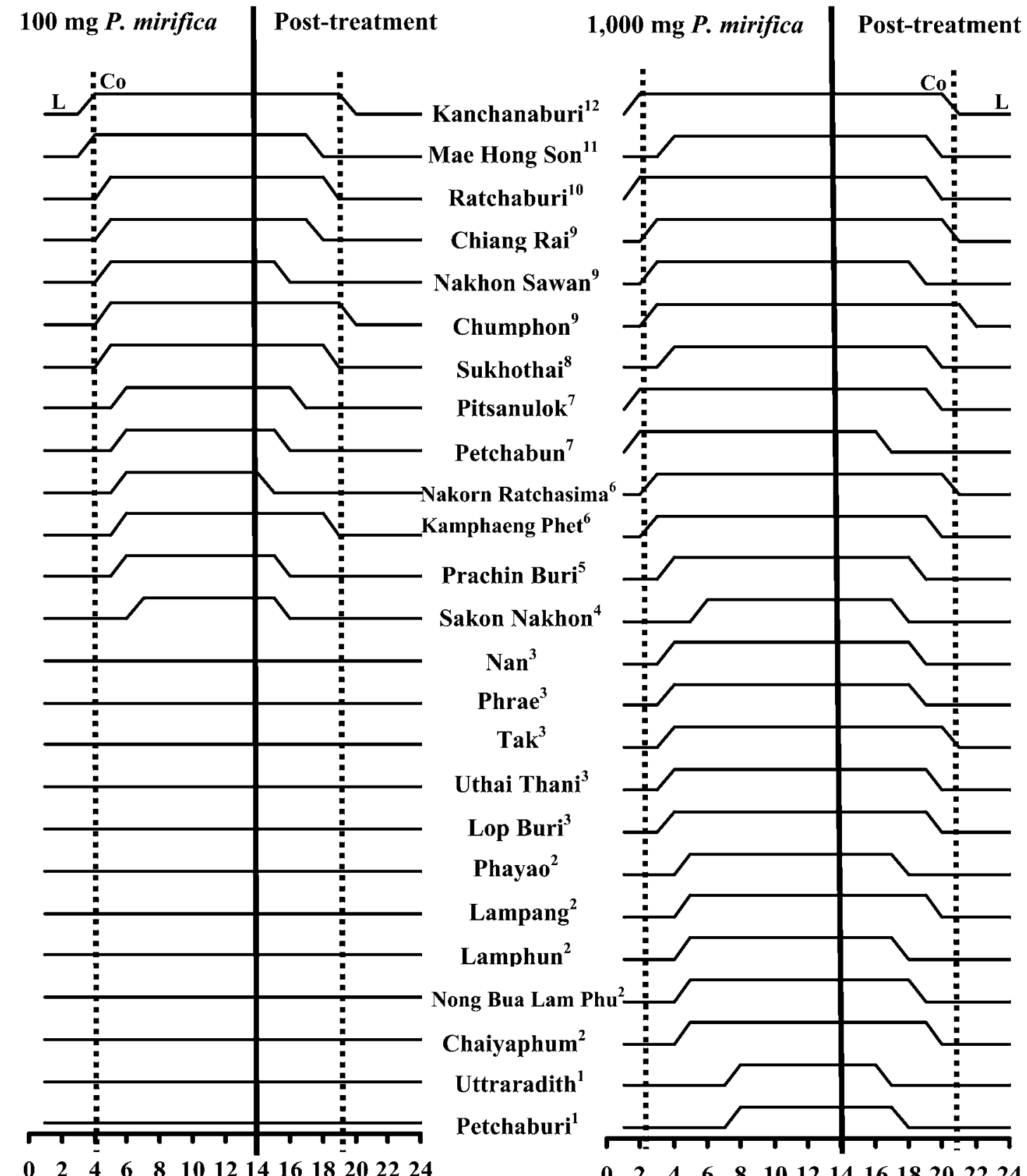

Kanchanaburi ${ }^{12}$

Mae Hong Son ${ }^{11}$

Ratchaburi $^{10}$

Chiang Rai ${ }^{9}$

Nakhon Sawan'

Chumphon"

Sukhothai ${ }^{8}$

Pitsanulok $^{7}$

Petchabun $^{7}$

Nakorn Ratchasima Kamphaeng Phet ${ }^{6}$

Prachin Buri $^{5}$

Sakon Nakhon ${ }^{4}$

$\mathrm{Nan}^{3}$

Phrae $^{3}$

$\mathrm{Tak}^{3}$

Uthai Thani $^{3}$

Lop Buri ${ }^{3}$

Phayao $^{2}$

Lampang $^{2}$

Lamphun ${ }^{2}$

Nong Bua Lam Phu

Chaiyaphum $^{2}$

Uttraradith $^{1}$

Petchaburi ${ }^{1}$
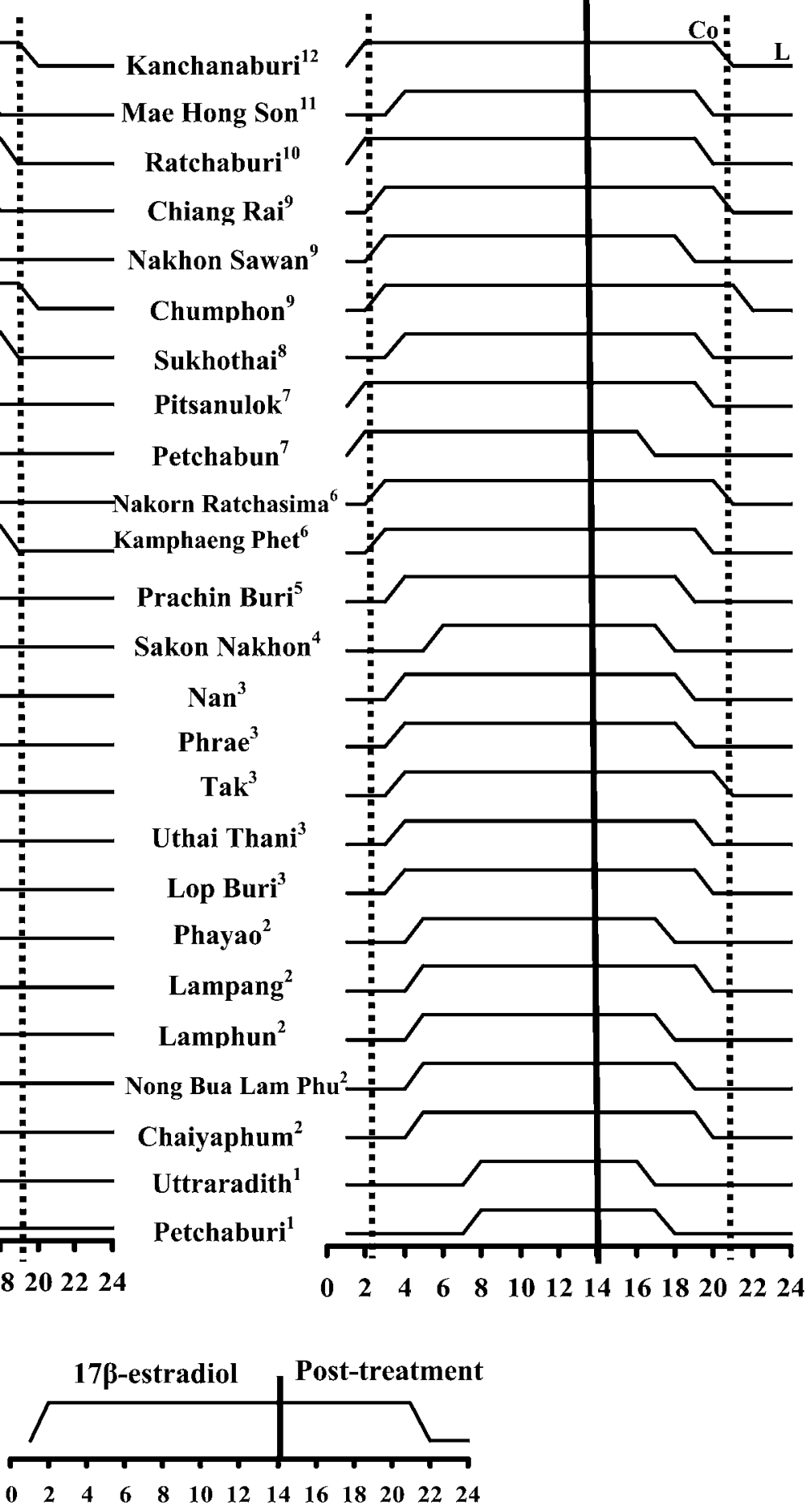

\section{Days}

Fig. 1. The appearance of cornified cells in ovariectomized rats treated with 100 and $1,000 \mathrm{mg} / \mathrm{kg}$ BW of $P$. mirifica and $17 \beta$-estradiol. The graphs for each $P$. mirifica treatment are ranked sequentially in accordance with their estrogenic bioactivity from 12 (highest activity) to 1 (lowest activity) as shown by superscript numbers. " $L$ " and "Co" stand for the "leukocyte" and "cornified" cells. The vertical dotted lines indicate the first and last days of Co-type cell occurrence in the 100 and $1,000 \mathrm{mg} / \mathrm{kg} \mathrm{BW}$ of $P$. mirifica groups. The vertical line indicates the last day of the treatment period. 


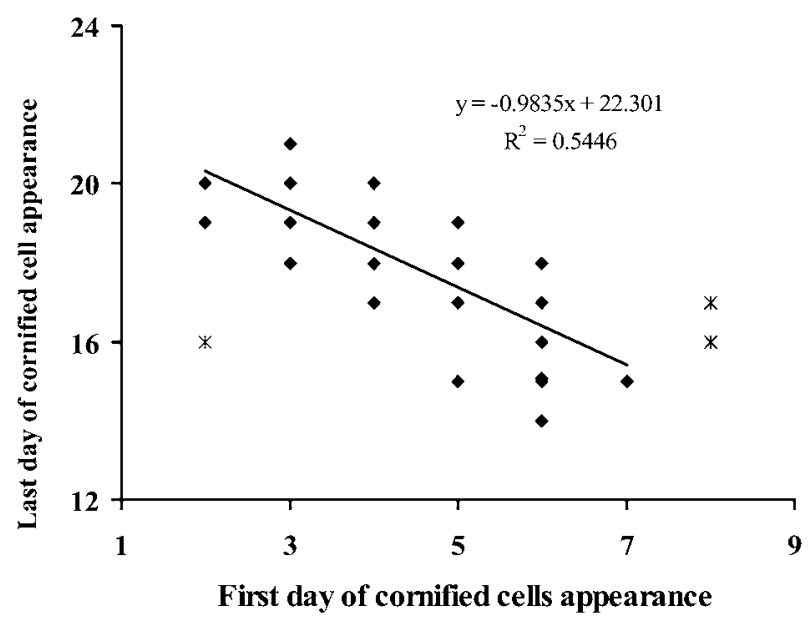

Fig. 2. Correlation analysis of the last day of cornified cell appearance and the first day of cornified cell appearance.

same first day of the Co-type cell appearance after treatment with 100 and $1,000 \mathrm{mg} / \mathrm{kg}$ BW of $P$. mirifica. Thus, calculation of the percentage of cornified cells should resolve this ranking problem.

The two cultivars of $P$. mirifica with the highest estrogenic activity, Kanchanaburi and Mae Hong Son, were selected and compared the percentage of cornified cells. The estrogenic activity calculated by the percentage of cornified cells resembled the results of the first day of Co-type cell appearance. That is, the percentage of cornified cells for $2 \mathrm{mg} /$ $\mathrm{kg}$ BW of $17 \beta$-estradiol was higher than for the Kanchanaburi, Mae Hong Son cultivars and distilled water, respectively (Table 2).

\section{Discussion}

P. mirifica phytoestrogens were found to have a dose-dependent estrogenic effect on rat vaginal cornification. A dose of $10 \mathrm{mg} / \mathrm{kg}$ BW from all plant samples did not produce a rat vaginal cornification, and only 13 of 25 P. mirifica samples induced a vaginal cornification at a dose of 100 $\mathrm{mg} / \mathrm{kg} \mathrm{BW}$. The responses in the P. mirifica-treated rats were initiated by binding of phytoestrogens with the $\operatorname{ER} \beta$ and $\alpha$ type vaginal epithelial [27, 28]. Binding affinity to ER $\alpha$ and initiation of estrogenic response by $P$. mirifica has also been demonstrated in ER $\alpha$ human breast adenocarcinoma, MCF-7 [15]. The phytoestrogen concentrations in the blood

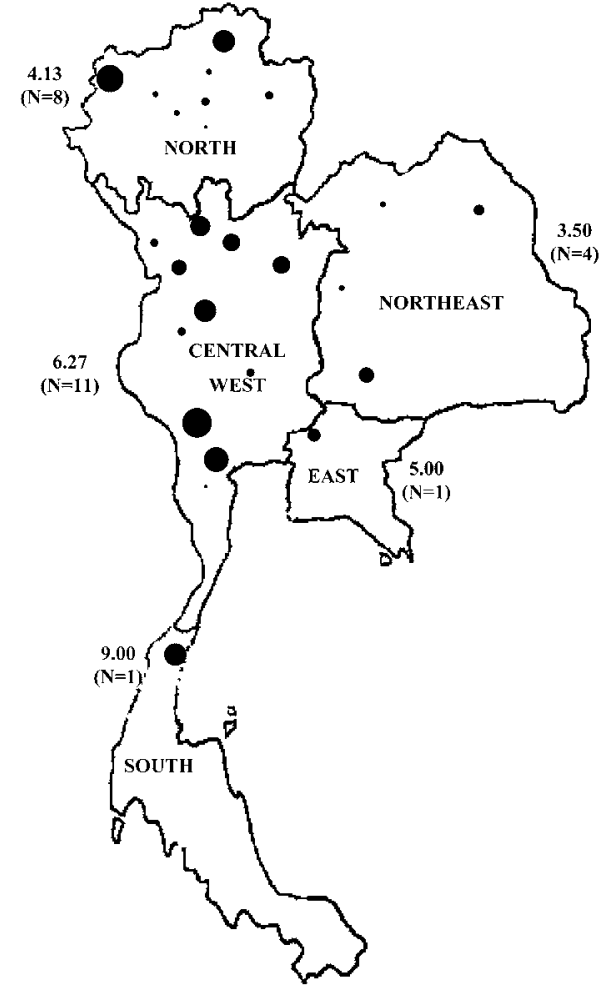

Fig. 3. A map of Thailand showing distribution of P. mirifica populations in 25 of the 76 provinces of Thailand. The degree of estrogenic activity is represented by the size of the circles.

circulation of the animals treated with $100 \mathrm{mg} / \mathrm{kg}$ BW P. mirifica samples have been too low compared with the maximum binding amount to ER, and thus the maximum estrogenic response could not be attained. This assumption was confirmed by induction of vaginal cornification occurring in all the rats after they were treated with a higher dose $(1,000 \mathrm{mg} / \mathrm{kg} \mathrm{BW})$ of P. mirifica. In conclusion, the $P$. mirifica collected from different provinces exhibited great variation in estrogenic activity in terms of the vaginal cornification assay. The plants showing the highest estrogenic activity also maintained activity for a longer period. The plant sample from the Kanchanaburi cultivar exhibited the highest estrogenic activity and longest duration of action. Thus, the Kanchanaburi cultivar should be a candidate of choice for large-scale cultivation. Taken together, selection of the wild P. mirifica for cultivation to serve the market demand should take into consideration not only the estrogenic action of the plant but also profit calculations related to 
Table 1. Regions, collection sites, estrogenic bioactivity, and first day of cornified cells appearance after daily treatment with 100 and $1,000 \mathrm{mg} / \mathrm{kg} \mathrm{BW/} \mathrm{of} P$. mirifica for each cultivar

\begin{tabular}{|c|c|c|c|c|}
\hline \multirow[t]{2}{*}{ Region } & \multirow{2}{*}{$\begin{array}{l}\text { Collection sites } \\
\text { (province) }\end{array}$} & \multirow{2}{*}{$\begin{array}{l}\text { Estrogenic } \\
\text { bioactivity }^{\mathrm{a}}\end{array}$} & \multicolumn{2}{|c|}{ First day of cornified cells appearance } \\
\hline & & & $100 \mathrm{mg}$ P. mirifica & $1,000 \mathrm{mg}$ P. mirifica \\
\hline \multirow[t]{9}{*}{ North } & Mae Hong Son & 11 & 4 & 4 \\
\hline & Chiang Rai & 9 & 5 & 3 \\
\hline & Nan & 3 & - & 4 \\
\hline & Phrae & 3 & - & 4 \\
\hline & Phayao & 2 & - & 5 \\
\hline & Lampang & 2 & - & 5 \\
\hline & Lamphun & 2 & - & 5 \\
\hline & Uttraradith & 1 & - & 8 \\
\hline & $\mathrm{N}=8$ provinces & $4.13 \pm 1.32$ & $11.63 \pm 1.56^{\mathrm{b}}$ & $4.75 \pm 0.53$ \\
\hline \multirow{5}{*}{ Northeast } & Nakorn Ratchasima & 6 & 6 & 3 \\
\hline & Sakon Nakhon & 4 & 7 & 6 \\
\hline & Nong Bua Lam Phu & 2 & - & 5 \\
\hline & Chaiyaphum & 2 & - & 5 \\
\hline & $\mathrm{N}=4$ provinces & $3.50 \pm 0.96$ & $10.25 \pm 2.17^{b}$ & $4.75 \pm 0.63$ \\
\hline \multirow[t]{12}{*}{ Central-West } & Kanchanaburi & 12 & 4 & 2 \\
\hline & Ratchaburi & 10 & 5 & 2 \\
\hline & Nakorn Sawan & 9 & 5 & 3 \\
\hline & Sukhothai & 8 & 5 & 4 \\
\hline & Phitsanulok & 7 & 6 & 2 \\
\hline & Phetchabun & 7 & 6 & 2 \\
\hline & Kamphaeng Phet & 6 & 6 & 3 \\
\hline & Tak & 3 & - & 4 \\
\hline & Uthai Thani & 3 & - & 4 \\
\hline & Lop Buri & 3 & - & 4 \\
\hline & Phetchaburi & 1 & - & 8 \\
\hline & $\mathrm{N}=11$ provinces & $6.27 \pm 1.04$ & $8.45 \pm 1.34^{\mathrm{b}}$ & $3.45 \pm 0.53$ \\
\hline East & Phrachin Buri & 5.00 & 6 & 4 \\
\hline South & Chumphon & 9.00 & 5 & 3 \\
\hline
\end{tabular}

Dashes indicate "no" cornified cells were observed during the treatment period.

a Estrogenic bioactivity was arbitrarily designated as a number from 1 to 12 based on the first day of cornified cell appearance after daily treatment with 100 and $1,000 \mathrm{mg} / \mathrm{kg}$ BW of $P$. mirifica for each cultivar (a detailed explanation is included in the text).

${ }^{b}$ Fourteen (the $14^{\text {th }}$ day) was used as the first day of cornified cell appearance for calculations when no cornified cells were observed for daily cultivar treatment of $100 \mathrm{mg} / \mathrm{kg}$ BW/day.

Table 2. The percentage of rat cornified cells counted on the $4^{\text {th }}$ day of the treatment period for $100 \mathrm{mg} / \mathrm{kg} \mathrm{BW}$ P. mirifica, distilled water and $\mathrm{E}_{2}$

\begin{tabular}{lc}
\hline Treatment & Percentage of cornified cells \\
\hline $17 \beta$-estradiol (positive control) & 100 \\
Kanchanaburi & $81.20 \pm 3.12$ \\
Mae Hong Son & $52.80 \pm 4.09$ \\
Distilled water (negative control) & 0 \\
\hline
\end{tabular}

cultivation cost such as tuber size and the growth rate of plants.

There are at least three methods popularly used to investigate the estrogenic activity of synthetic estrogens, xenoestrogens, and phytoestrogens.
These methods include yeast estrogen screening (YES) of recombinant yeast cells [29, 30], proliferation assay with MCF-7 cells (E-assay) [30, 31] and uterotrophic assay in rodents [32]. Although the YES and E-assay methods are rapid methods, the results can not be transformed and applied to humans directly because metabolism (absorption, distribution and biotransformation) of estrogens and estrogen-like substances in humans is different from those of yeast and MCF-7 cells. Use of the uterotrophic assay in rodents seems to be the candidate of choice to resolve this problem. However, the uterotrophic assay has two disadvantages; firstly we need to kill the animals, and secondly we can not follow up changes of the 
uterus weight during the treatment and posttreatment periods. Recently, we reported a sensitive, simple, and inexpensive method for evaluation of the estrogenic activity of synthetic estrogens and phytoestrogen-rich herbs [33]. This method uses the vaginal cornification assay in ovariectomized rats. We compared the estrogenic activity of those substances between the uterotrophic and vaginal cornification assays and obtained the similar results. Moreover, the vaginal cornification assay resolves the two disadvantages of the uterotrophic assay.

Screening of the estrogenic activity of $P$. mirifica by the vaginal cornification assay is sensitive, simple, and inexpensive. However, this method has the following weaknesses: 1 ) the results are expressed as a non-continuous number (or all-ornone); including stimulation or no stimulation of Co-type cells and 2) two (or more) plants always show the same estrogenic activity ranking. This problem can be resolved by calculation of the percentage of cornified cells.

It had been realized that Phytoestrogen Replacement Therapy (PRT) is an effective alternative for Estrogen Replacement Therapy (ERT). This study confirmed the differential estrogenic effect of wild P. mirifica collected from a majority of the plant population, 25 out of a total of 76 provinces in Thailand using the vaginal cornification assay. A similar study with Pueraria Radix, a plant with tubers and high amount of isoflavone, especially puerarin has also been conducted. In that study the estrogenic activity of $P$. Radix tubers collected from many parts of Korea were compared using uterotrophic assay with that of $P$. mirifica collected from Thailand. None of the collected samples of $P$. Radix expressed an uterotrophic effect, although the Thai $P$. mirifica did. The authors concluded that the isoflavone contents in P. Radix were not related to estrogenic activity [34].

Considering the variability in the estrogenic activity of $P$. mirifica by region, the plants of the Central-West region showed high estrogenic activity in accordance with the phytoestrogen contents analyzed by HPLC [24]. Our investigation into the major isoflavonoid contents of the Thai $P$. mirifica population is intriguing because of the great diversity of puerarin, daidzin, genistin, daidzein and genistein in the plant tubers collected from the different sites. This is probably being one of the reasons why the plant tubers derived from different collection sites also varied in estrogenic activity. A possible explanation for this may be that the forest type and climate of the Central-West region may critical for plant growth [35]. This conclusion could be more precise if the differences in plant genetics are clarified because both genetics and environment, especially geographic distribution, could influence the isoflavone contents of plant materials [36]. The results of this study should benefit not only ranking of the quality of the P. mirifica plants based on the strength of their estrogenic activity but also individuals who need to farm the $P$. mirifica plants or process their tuber products. Based on the latest information we have obtained, it is possible that Thai P. mirifica populations have high potential to be introduced as an effective herbal phytoestrogen source $[13,15-$ 22]. The plant should be considered the most potent phytoestrogen source for replacement of estrogen therapy.

\section{Acknowledgements}

This work was supported by the Office of Commission for Higher Education-CU Graduate Thesis Grant and the grant for Primate Research Unit of Chulalongkorn University.

\section{References}

1. Bounds DG, Pope GS. Light absorption and chemical properties of miroestrol, the estrogenic substance of Pueraria mirifica. J Chem Soc 1960; 739: 3196-3705.

2. Tayler NE, Hodgkin DC. The X-ray crystallographic determination of the structure of bromomiroestrol. J Chem Soc 1960; 33: 3685-3695.
3. Jones HGH, Pope GS. A study of action of miroestrol and other oestrogen on the reproductive tract of the immature female mouse. J Endrocrinol 1960; 20: 229-235.

4. Chansakaow S, Ishikawa T, Seki H, Sekine K, Okada M, Chaichantipyuth C. Identification of deoxymiroestrol as the actual rejuvenating principle 
of "Kwao Keur", Pueraria mirifica. The known miroestrol may be an artifact. J Nat Prod 2000; 63: 173-175.

5. Ingham JL, Markham KR, Dziedzic SZ, Pope GS. Puerarin 6' O- $\beta$-apiofuranoside, a C-glycosylisoflavone O-glycoside from Pueraria mirifica. Phytochemistry 1986; 25: 1772-1775.

6. Ingham JL, Tahara S, Dziedzic SZ. A chemical investigation of Pueraria mirifica roots. Z Naturforsc C 1986; 41c: 403-408.

7. Ingham JL, Tahara S, Dziedzic SZ. Coumestans from the root of Pueraria mirifica. Z Naturforsch C 1988; 43c: $5-10$.

8. Ingham $\mathbf{J L}$, Tahara $\mathbf{S}$, Dziedzic SZ. Minor isoflavones from the root of Pueraria mirifica. Z Naturforsch C 1989; 44c: 724-726.

9. Tahara S, Ingham I, Dziedzic SZ. Structure elucidation of kwakhurin, a new phenylated isoflavone from Pueraria mirifica root. Z Naturforsch C 1987; 42c: 510-518.

10. Chansakaow S, Ishikawa T, Sekine K, Okada M, Higuchi Y, Kudo M, Chaichantipyuth C. Isoflavonoids from Pueraria mirifica and their estrogenic activity. Planta Med 2000; 66: 572-575.

11. Benson GK, Cowie AT, Hosking ZD. Mammogenic activity of miroestrol. J Endrocrinol 1961; 21: 401-409.

12. Jones HEH, Waynforth HB, Pope GS. The effect of miroestrol on vaginal cornification, pituitary function and pregnancy in the rat. J Endrocrinol 1961; 22: 303-312.

13. Muangman $\mathbf{V}$, Cherdshewasart $\mathbf{W}$. Clinical trial of the phytoestrogen-rich herb, Pueraria mirifica as a crude drug in the treatment of symptoms in menopausal women. Siriraj Hosp Gaz 2001; 53: 300309.

14. Cherdshewasart W. Toxicity tests of a phytoestrogen-rich herb; Pueraria mirifica. I Sci Res Chulalongkorn Univ 2003; 28: 1-12.

15. Cherdshewasart W, Cheewasopit W, Picha P. The differential anti-proliferation effect of white (Pueraria mirifica), red (Butea superba), and black (Mucuna collettii) Kwao Krua plants on the growth of MCF-7 cells. J Ethnopharmacol 2004; 93: 255-260.

16. Cherdshewasart W, Cheewasopit W, Picha P. Antiproliferation effects of the white (Pueraria mirifica), red (Butea superba) and black (Mucuna collettii) Kwao Krua plant on the growth of HeLa cells. J Sci Res Chulalongkorn Univ 2004; 29: 27-31.

17. Malaivijitnond S, Kiatthaipipat $\mathbf{P}$, Cherdshewasart W, Watanabe G, Taya K. Different effect of Pueraria mirifica, an herb containing phytoestrogens, on LH and FSH secretion in gonadectomized female and male rats. J Pharmacol Sci 2004; 96: 428-435.

18. Trisomboon H, Malaivijitnond S, Watanabe G, Taya K. Estrogenic effect of Pueraria mirifica on the menstrual cycle and hormones related ovarian function in cyclic female cynomolgus monkeys. J
Pharmacol Sci 2004; 94: 51-59.

19. Trisomboon $\mathbf{H}$, Malaivijitnond S, Suzuki J, Hamada Y, Watanabe G, Taya K. Long-term treatment effects of Pueraria mirifica phytoestrogens on parathyroid hormone and calcium levels in aged menopausal cynomolgus monkeys. J Reprod Dev 2004; 50: 639-645.

20. Trisomboon H, Malaivijitnond S, Watanabe G, Taya K. Ovulation block by Pueraria mirifica. Endocrine 2005; 26: 33-39.

21. Trisomboon H, Malaivijitnond S, Watanabe G, Cherdshewasart $\mathbf{W}$, Taya $\mathbf{K}$. The estrogenic effect of Pueraria mirifica on gonadotrophin levels in aged monkeys. Endocrine 2006; 31: 129-134.

22. Trisomboon $\mathbf{H}$, Malaivijitnond $\mathbf{S}$, Cherdshewasart W, Watanabe G, Taya K. Effect of Pueraria mirifica on the sexual skin coloration of aged menopausal cynomolgus monkeys. J Reprod Dev 2006: 52: 537542.

23. Sukavattana T. Oestrogenic principle of Butea superba, preliminary report. J Med Assoc Thai 1940; 24: 183-194.

24. Cherdshewasart W, Subtang S, Dahlan W. Major isoflavonoid contents of the phytoestrogen rich-herb Pueraria mirifica in comparison with Pueraria lobata. J Pharm Biomed Anal 2007; 43:428-434.

25. Kashemsanta MLC, Suvatabandhu K, Airy SHK. A new species of Pueraria (Leguminosae) from Thailand, yielding an oestrogenic principle. Kew Bulletin 1952; 263-266.

26. Terenius L. The Allen Doisy test for estrogens reinvestigated. Steroids 1971; 17: 613-618.

27. Kuiper GGJ, Carlsson B, Grandien K, Enmark E, Haggblad J, Nilsson S, Gustafsson JA. Comparison of the ligand binding specificity and transcript tissue distribution of estrogen receptor $\alpha$ and $\beta$. Endocrinology 1997; 138: 863-870.

28. Kuiper GGJ, Lemmen JG, Carlsson B, Corton JC, Safe SH, van der Saag PT, van der Burg B, Gustafsson JA. Interaction of estrogenic chemicals and phytoestrogens with estrogen receptor $\beta$. Endocrinology 1998; 139: 4252-4263.

29. Breithofer A, Graumann K, Scicchitano MS, Karatahnasis K, Butt TR, Jungbauer A. Regulation of human estrogen receptor by phytoestrogen in yeast and human cells. J Steroid Biochem Molec Biol 1998; 67: 421-429.

30. Lee YS, Park LS, Cho SD, Son JK, Cherdshewasart W, Kang KS. Requirement of metabolic activation for estrogenic activity of Pueraria mirifica. J Vet Sci 2002; 3: 273-277.

31. Boue SM, Wiess TE, Nehls S, Burow ME, Elliott $S$, Carter-Wientjes CH, Shih BY, McLachlan JA, Cleveland TE. Evaluation of the estrogenic effects of legume extracts containing phytoestrogens. J Agri Food Chem 2003; 51: 2193-2199.

32. Jefferson WN, Padilla-Banks E, Clark G, Newbold 
RR. Assessing estrogen activity of phytochemicals using transcriptional activation and immature mouse uterotrophic responses. J Chromatography 2002; B 777: 179-189.

33. Malaivijitnond S, Chansri K, Kijkuokul P, Urasopon $\mathbf{N}$, Cherdshewasart $\mathbf{W}$. Using vaginal cytology to assess the estrogenic activity of phytoestrogen-rich herbs. J Ethnopharmacol 2006; 107: 354-360.

34. Kim HY, Hong JH, Kim DS, Kang KJ, Han SB, Lee EJ, Chung HW, Song KH, Sho KA, Kwack SJ, Kim
SS, Park KL, Kim MC, Kim CM, Song IS. Isoflavone content and estrogenic activity in arrowroot Puerariae Radix. Food Technol Biotechnol 2003; 12: 29-35.

35. Bachelet D, Brown D, Bohm M, Russell P. Climate change in Thailand and its potential impact on rice yield. Climatic Change 1992; 21: 347-366.

36. Joseph AH, Walter RF, Patricia AM, Grace AW. Influence of genotype and environment on isoflavone contents of soybean. Crop Sci 2000; 40: 4851. 